\title{
1 A Novel L-Serine Exporter and Its Positive Regulator in Corynebacterium \\ 2 glutamicum
}

3 Xiaomei Zhang ${ }^{1}$, Yujie $\mathrm{Gao}^{1}$, Ziwei Chen ${ }^{1}$, Guoqiang $\mathrm{Xu}{ }^{2,3}$, Xiaojuan Zhang ${ }^{2,3}$, Hui

$4 \mathrm{Li}^{1}$, Jinsong Shi ${ }^{1}$, Mattheos Koffas ${ }^{4,5^{*}}$, Zhenghong $\mathrm{Xu}^{2,3^{*}}$

$5{ }^{1}$ Laboratory of Pharmaceutical Engineering, School of Pharmaceutics Science, Jiangnan

6 University, Wuxi, People's Republic of China

$7 \quad{ }^{2}$ National Engineering Laboratory for Cereal Fermentation Technology, Jiangnan

8 University, Wuxi, People's Republic of China

$9{ }^{3}$ The Key Laboratory of Industrial Biotechnology, Ministry of Education, School of

10 Biotechnology, Jiangnan University, Wuxi, People's Republic of China

$11{ }^{4}$ Department of Chemical and Biological Engineering, Rensselaer Polytechnic Institute,

12 Troy NY, USA

$13{ }^{5}$ Department of Biological Sciences, Rensselaer Polytechnic Institute, Troy NY, USA

14 Corresponding author.

15 E-mail address: koffam@rpi.edu

16 E-mail address: zhenghxu@jiangnan.edu.cn 


\section{ABSTRACT}

20 Exporters play an essential role in the fermentative production of amino acids. In

21 Corynebacterium glutamicum, ThrE, which can export L-threonine and L-serine, is the

22 only identified L-serine exporter so far. In this study, a novel L-serine exporter NCg10580

23 was identified and characterized in C. glutamicum $\triangle$ SSAAI (SSAAI), and named as SerE

24 (encoded by serE). Deletion of $\operatorname{serE}$ in SSAAI led to a 56.5\% decrease in L-serine titer,

25 whereas overexpression of $\operatorname{ser} E$ compensated for the lack of $\operatorname{ser} E$ with respect to L-serine

26 titer. A fusion protein with SerE and enhanced green fluorescent protein (EGFP) was

27 constructed to confirm that SerE localized at the plasma membrane. The function of SerE

28 was studied by peptide feeding approaches, and the results showed that SerE is a novel

29 exporter for L-serine and L-threonine in C. glutamicum. Subsequently, the interaction of a

30 known L-serine exporter ThrE and SerE was studied, and the results suggested that SerE

31 is more important than ThrE in L-serine export in SSAAI. Probe plasmid and

32 electrophoretic mobility shift assays (EMSA) revealed NCg10581 as the transcriptional

33 regulator of SerE. Comparative transcriptomics between SSAAI and the NCg10581

34 deletion strain showed that $\mathrm{NCg} 10581$ regulated the transcription of 115 genes in $C$.

35 glutamicum, among which the transcriptional level of NCg10580 decreased 280-fold in a 
36 NCg10581 deletion strain, indicating that NCg10581 is a positive regulator of SerE. Thus,

37 this study provides a novel target for L-serine and L-threonine export engineering as well

38 as a novel global transcriptional regulator $\mathrm{NCg10581} \mathrm{in} \mathrm{C.} \mathrm{glutamicum.}$

\section{Importance}

40 Exporters are gaining increasing attention for improving industrial production of amino

41 acids. This study identified a novel exporter NCg10580 for L-serine and L-threonine in $C$.

42 glutamicum, and its positive regulator (NCg10581), which was shown to be a novel global

43 transcriptional regulator in C. glutamicum. This study provides a new target for

44 engineering efflux of L-serine and L-threonine, expands the exporter and transcriptional

45 regulator family, and enriches our understanding of amino acid transport system in $C$.

46 glutamicum.

47 KEYWORDS L-serine, exporter, C. glutamicum, transcriptional regulator, metabolic

48 engineering

\section{INTRODUCTION}

50 L-serine has been identified as one of the top 30 most interesting building blocks for a

51 range of chemicals and materials, and is used in cosmetic, pharmaceutical, and food

52 industries $(1,2)$. Metabolic engineering of Corynebacterium glutamicum (C. glutamicum)

53 for L-serine production has been focused on its terminal synthesis pathways and 
54 degradation pathways, and proven to be very useful for improving L-serine production in

55 this organism (3-6); however, the L-serine productivity is still low for large-scale L-serine

56 production.

57 Efflux is often overlooked as a bottleneck in metabolic pathways, and amino acid

58 efflux transporters are increasingly gaining attention for optimizing industrial production

59 of amino acids $(7,8)$. In recent decades, a number of export systems have been identified

60 for excreting amino acids, such as L-lysine, L-cysteine, L-glutamate, L-threonine, L-

61 arginine, L-methionine, and branched-chain amino acids, in C. glutamicum and

62 Escherichia coli (8-14). However, to the best of our knowledge, except for ThrE (L-

63 threonine and L-serine exporter) $(12,15)$, no other L-serine exporters have been reported

64 in C. glutamicum so far. In E. coli, Mundhada et al. found that intracellular L-serine

65 accumulation was toxic to the engineered strain modified to produce L-serine, and that

66 following overexpression of eamA (which encodes L-cysteine exporter in E. coli), the

67 engineered strain exhibited increased tolerance toward L-serine with higher L-serine

68 productivity (1). Therefore, L-serine exporter in C. glutamicum could be a potential target

69 for strain optimization to further improve L-serine production.

70 It has been reported that homologs similar to the exporters in E. coli might fulfil a

71 comparable function in $C$. glutamicum $(14,16,17)$. Accordingly, we hypothesized that 
72 the homolog to eamA (L-serine exporter in E. coli) (1) might be involved in L-serine

73 export in C. glutamicum. In the present study, three homologs to eamA, namely,

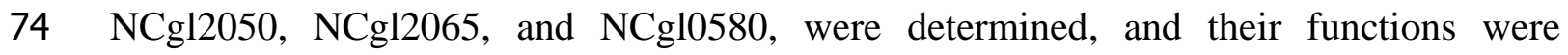

75 identified by targeted gene deletion, respectively. The results showed that one of the

76 genes, NCg10580, was involved in L-serine export. Subsequently, localization and

77 function of NCg10580 were investigated, and the interaction of a known L-serine exporter

78 ThrE (encoded by thrE) and the novel exporter NCg10580 was studied. Furthermore, the

79 transcriptional regulator of NCg10580 was identified and studied.

80 RESULTS

81 Exploring putative L-serine exporters in C. glutamicum. In past studies, homologs of $E$.

82 coli exporters have been shown to have similar functions in C. glutamicum $(14,16,17)$.

83 Therefore, we hypothesized that the C. glutamicum homolog to eamA (L-serine exporter

84 in E. coli) (1) might be involved in L-serine export in this organism. According to the

85 NCBI database, EamA belongs to the RhaT superfamily, and 15 records of related

86 proteins associated with RhaT superfamily in C. glutamicum ATCC13032 were obtained.

87 After eliminating duplicate records, three related genes, NCg12050, NCg12065, and

88 NCg10580, were obtained, which might be involved in L-serine export in C. glutamicum. 
89 To verify the function of these putative proteins in C. glutamicum SSAAI (SSAAI),

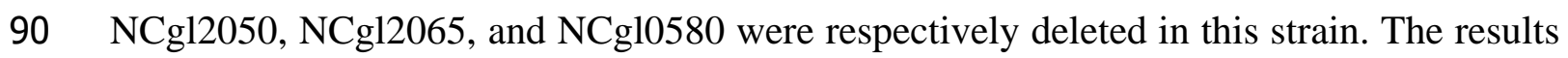

91 showed that the deletion of NCg12050 and NCgl2065 did not produce any changes in cell

92 growth and L-serine titer (Fig. 1A and 1B). Strikingly, deletion of NCg10580 significantly

93 reduced the L-serine titer in SSAAI, but did not affect the growth of the strain (Fig. 1C).

94 SSAAI $\triangle \mathrm{NCg} 10580$ produced $11.31 \mathrm{~g} / \mathrm{L}$ L-serine, which was $56.5 \%$ lower than that noted

95 in SSAAI (Fig. 1C). However, plasmid-borne overexpression of NCg10580 compensated

96 for the lack of $\mathrm{NCg} 10580$ with respect to L-serine titer, resulting in $26.76 \mathrm{~g} / \mathrm{L} \mathrm{L-serine} \mathrm{titer,}$

97 similar to that generated by the parent strain SSAAI (Fig. 1D). As shown in Fig. 1D,

98 when compared with SSAAI, the strain harboring the plasmid grew slowly to some extent

99 in the logarithmic growth phase, finally reaching similar cell growth to SSAAI. This

100 finding suggested that $\mathrm{NCg10580} \mathrm{might} \mathrm{act} \mathrm{as} \mathrm{the} \mathrm{L-serine} \mathrm{exporter} \mathrm{in} \mathrm{C.} \mathrm{glutamicum,} \mathrm{and}$

101 was named as SerE and its function was further investigated.

102 Localization and function of SerE. According to the NCBI, SerE was presumed to be

103 a hypothetical membrane protein of 301 amino acids, similar to permease of the

104 drug/metabolite transporter (DMT) superfamily. The transmembrane helices of SerE were

105 predicted by TMHMM Server v. 2.0, and SerE exhibited ten transmembrane-spanning

106 helices with both amino- and carboxy-terminal ends in the cytoplasm. 
107 To confirm the localization of SerE, SerE-EGFP fusion protein was expressed in

108 SSAAI. Confocal microscopic observations of SSAAI-egfp and SSAAI-serE-egfp

109 confirmed that EGFP and SerE-EGFP fusion proteins were successfully expressed,

110 respectively (Fig.S1). To further verify the localization of SerE, membrane and

111 cytoplasmic proteins from these two strains were extracted by ultrasonication, and the

112 fluorescence of these proteins was determined using a fluorescence spectrophotometer.

113 The fluorescence of the cytoplasmic proteins of SSAAI-egfp and membrane proteins of

114 SSAAI-serE-egfp (Fig. 2) affirmed that SerE was localized at the plasma membrane in

115 SSAAI.

116 To substantiate the function of SerE, a peptide feeding approach was employed by

117 incubating SSAAI and SerE deletion strain, SSAAI $\Delta s e r E$, with $2 \mathrm{mM}$ of the dipeptide

118 Ser-Ser, respectively, and measuring the concentration of extracellular L-serine. As shown

119 in Fig. 3A, a higher L-serine concentration was detected in SSAAI, when compared with

120 that in SSAAI $\Delta s e r E$, confirming that SerE is a novel exporter of L-serine in $C$.

121 glutamicum.

122 It is known that L-cysteine uptake system in E. coli (encoded by eamA) also catalyzes

123 L-serine uptake (1), and that L-threonine exporter in C. glutamicum (encoded by thrE) also

124 transports L-serine (12). We therefore analyzed whether the novel exporter SerE could 
125 uptake L-cysteine and L-threonine. The export experiments with dipeptides (Thr-Thr, Cys-

126 Cys) were performed using SSAAI and SSAAI $\Delta s e r E$. The dipeptides were added at a

127 concentration of $2 \mathrm{mM}$ to the medium, and the extracellular amino acid concentrations at

128 different time intervals were determined by HPLC. The results revealed that the

129 concentration of L-cysteine was comparable in both strains and did not significantly

130 change (data not shown), indicating that SerE does not export L-cysteine. Interestingly,

131 the concentrations of L-threonine in SSAAI $\Delta \operatorname{serE}$ were lower than those in SSAAI (Fig.

132 3B), indicating that SerE is also an exporter of L-threonine in C. glutamicum.

133 Interaction of ThrE and SerE. It is well known that $t h r E$ encodes ThrE that can

134 export L-threonine and L-serine in C. glutamicum ATCC13032 (12). To understand the

135 interaction of ThrE and SerE on L-serine uptake, thrE was deleted in SSAAI (SSAAI

$136 \Delta t h r E$ ), and no significantly change was observed in L-serine uptake for the deletion

137 mutant (Fig. 4A). In contrast, deletion of SerE significantly reduced the L-serine titer in

138 SSAAI, and resulted in a slight change in cell growth (Fig. 1C). The SSAAI $\Delta \operatorname{serE}$

139 produced $11.31 \mathrm{~g} / \mathrm{L}$ L-serine, which was $56.5 \%$ lower than that produced by SSAAI (Fig.

140 1C). Subsequently, thrE and serE double deletion mutant was constructed, which

141 exhibited cell growth comparable to that of SSAAI (Fig. 4B), and produced $10.34 \mathrm{~g} / \mathrm{L} \mathrm{L-}$

142 serine, which was $60 \%$ lower than that observed in SSAAI (Fig. 4C). 
143 Furthermore, $t h r E$ and $\operatorname{ser} E$ were overexpressed in SSAAI to obtain SSAAI-thrE and

144 SSAAI-serE respectively. While L-serine accumulation in SSAAI-thrE was similar to that

145 in SSAAI (Fig. 4A), the production of L-serine in SSAAI-serE reached $28.67 \mathrm{~g} / \mathrm{L}$, which

146 was $10.5 \%$ higher than that noted in SSAAI (Fig.4D). However, a decrease in cell growth

147 was observed in SSAAI-serE before $72 \mathrm{~h}$ of fermentation, when compared with that

148 found in SSAAI (Fig.4E). These results suggested that SerE is more important than ThrE

149 in L-serine export in SSAAI.

150 Transcriptional regulator of SerE. The gene NCg10581, located upstream of serE

151 and divergently transcribed from serE (Fig. S2), and its product (consisting of 303 amino

152 acids) were found to be members of the LysR-type transcriptional regulators (LTTRs)

153 family. It must be noted that LTTRs were initially described as regulators of divergently

154 transcribed genes (18). In a previous study on C. glutamicum, LysG, located upstream of

155 L-lysine exporter gene lysE, was observed to encode a LysR-type transcriptional

156 regulator, confirming that LysG is a positive transcriptional regulator of lysE (19).

157 Accordingly, we speculated that NCg10581 might be involved in the control of serE

158 transcription.

159 To determine the function of NCg10581, a mutant strain with NCg10581 deletion was

160 constructed. As shown in Fig. 5, the growth of SSAAI $\triangle$ NCg10581 was similar to that of 
161 the parent strain SSAAI. However, the L-serine titer of SSAAI $\Delta$ NCg10581 was $11.08 \mathrm{~g} / \mathrm{L}$,

162 which was $57.4 \%$ lower than that of the parent strain, indicating that NCg10581 played an

163 important role in L-serine production. Subsequently, the effect of NCg10581 on serE

164 expression was further investigated by using the probe plasmid pDXW-11. Two

165 recombinant strains, SSAAI $\triangle \mathrm{NCg10581-1} \mathrm{(harboring} \mathrm{the} \mathrm{plasmid} \mathrm{pDXW-11-1,} \mathrm{Fig.} \mathrm{S3A)}$

166 and SSAAI $\triangle \mathrm{NCg10581-0}$ (harboring the plasmid pDXW-11-0, Fig. S3B) were

167 constructed, and their fluorescence during fermentation was measured. The fluorescence

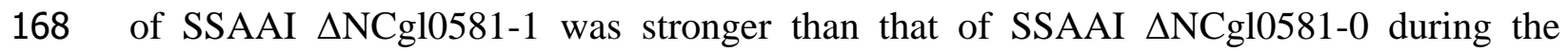

169 fermentation process (Fig. S3C), revealing that NCg10581 functioned as a positive

170 regulator of $\operatorname{serE}$ expression. To verify whether the regulatory protein $\mathrm{NCg} 10581$ binds to

171 the upstream region of SerE, electrophoretic mobility shift assay (EMSA) was performed

172 by using the DNA probe labeled with biotin, and the result clearly indicated that

173 NCgl0581 binds to this region (Fig. S4).

174 To confirm whether NCg10581 is a specific regulator of SerE, transcriptome

175 sequencing was performed using SSAAI and NCg10581 deletion strain. The findings

176 showed that the transcription levels of 115 genes were altered, including 56 genes

177 upregulated and 59 genes downregulated, in response to NCgl0581 deletion, indicating

178 that $\mathrm{NCg} 10581$ is a global transcriptional regulator in C. glutamicum. The genes with 
179 significant transcriptional change $(\geq 4$-fold) are shown in Tables 2 and 3 . The

180 transcriptional level of serE was significantly decreased by 280-fold following NCg10581

181 deletion, revealing that $\mathrm{NCgl0581}$ is a positive regulator of serE. Furthermore, NCg10581

182 deletion downregulated the two ABC transporter permeases (NCg10638 and $\mathrm{NCg10484)}$

183 and $\mathrm{ABC}$ transporter periplasmic component (NCg10639) by 12-, 6.3-, and 7.5-fold,

184 respectively, and upregulated $\mathrm{ABC}$ transporter periplasmic component (NCg11405) by

185 5.88-fold, suggesting that $\mathrm{NCgl0581}$ is involved in the synthesis of substances

186 transported through $\mathrm{ABC}$ transporter.

\section{DISCUSSION}

188 Transport engineering is becoming an attractive strategy for strain improvement $(8,13$,

189 14). However, only a relatively limited number of exporters of amino acids have been

190 identified in C. glutamicum (Table S1) $(9,11-14,20-24)$. In the present study, SerE was

191 identified as a novel L-serine exporter in C. glutamicum. Further analysis showed that

192 SerE could also uptake L-threonine (Fig. 3B), but not L-cysteine, similar to ThrE, which

193 can export both L-serine and L-threonine in C. glutamicum (12). It is assumed that the

194 presence of $-\mathrm{OH}$ in both L-serine and L-threonine might be the reason for these exporters

195 to transport the two substrates. Based on homology search, SerE was found to be similar

196 to a member of the DMT superfamily. Although DMT superfamily proteins are involved 
197 in the transport of a wide range of substrates, there are only a few reports available on

198 their structures and mechanisms of substrate transport. Tsuchiya et al. performed

199 structural and functional analyses of YddG, a DMT protein, and provided insight into the

200 common transport mechanism shared among the DMT superfamily members (25). It has

201 been reported that analyses of the crystal structure data of exporters could help to

202 elucidate the elusive transport mechanism (26), and in the future, we plan to investigate

203 further the SerE structures and mechanisms of substrate transport.

204 To explore the interaction between the known L-serine exporter ThrE and the novel

205 exporter SerE on L-serine uptake, ThrE and SerE single and double mutants were

206 constructed. The results showed that $\operatorname{ser} E$ and $t h r E$ double deletion mutant could still

207 accumulate $10.34 \mathrm{~g} / \mathrm{L}$ L-serine (Fig. 4), suggesting that $C$. glutamicum might also possess

208 other L-serine exporter systems. The evolution of multiple exporter systems for a single

209 substrate is beneficial for the survival of bacteria in variable environment $(7,27)$. It must

210 be noted that overexpression of serE in SSAAI resulted in $10.5 \%$ increase in L-serine titer,

211 but a decrease in cell growth. This could be due to the use of constitutive-type promoter

212 to overexpress SerE, which resulted in higher L-serine efflux. As sufficient L-serine

213 content is important to maintain cell growth, a decrease in cell growth was noted as a

214 stress response to $\operatorname{ser} E$ overexpression. In future studies, better tuning of the $\operatorname{ser} E$ 
215 expression will be performed in SSAAI by testing different promoters and RBS.

216 NCg10581 was identified as a SerE transcriptional regulator, and EMSA was performed

217 to confirm the binding sites of $\mathrm{NCg10581}$ with the promoter of SerE. A previous study

218 reported that the first member of the protein-gene pairs, ArgP-argO in E. coli and LysG-

219 lysE in C. glutamicum, is an LysR-type transcriptional regulator, while the second

220 member is its target gene encoding an amino acid exporter (19, 28, 29). Similarly,

221 NCg10581-serE might also be a protein-gene pair sharing the same regulation mechanism.

222 A serine-biosensor based NCgl0581 was reported by Binder et al. (30), and based on this

223 study, we constructed a biosensor for L-serine and found that NCg10581 activated

224 NCg10580 (SerE) expression in the presence of L-serine, the expression of NCg10580

225 enhancing with the L-serine titer increasing (31). However, NCg10581 did not activate the

226 expression of $\mathrm{NCg10580} \mathrm{in} \mathrm{the} \mathrm{presence} \mathrm{of} \mathrm{L-alanine} \mathrm{and} \mathrm{L-valine.} \mathrm{To} \mathrm{further} \mathrm{confirm}$

227 whether SerE could uptake L-alanine and L-valine, peptide feeding assays were employed

228 using dipeptides (Ala-Ala, Val-Val) with SSAAI and SSAAI $\Delta$ serE. The results revealed

229 that SerE could neither export L-alanine nor L-valine (data not shown). Moreover,

230 transcriptome sequencing showed that $\mathrm{NCg10581}$ regulated 115 genes in C. glutamicum,

231 suggesting that $\mathrm{NCgl0581}$ was a novel global transcriptional regulator in C. glutamicum.

232 Transcriptional regulators and their roles in expression control of target genes are 
233 important for metabolic engineering of C. glutamicum for industrial applications (32),

234 and this study provided a new member of transcriptional regulator family.

235 In conclusion, a novel exporter SerE and its positive regulator NCgl0581 were

236 identified in C. glutamicum, with SerE also exhibiting the ability to uptake L-threonine

237 and NCg10581 acting as a novel global transcriptional regulator in C. glutamicum. These

238 results enrich our understanding of amino acid transport and can provide additional

239 targets for exporter engineering in C. glutamicum.

240 MATERIALS AND METHODS

241 Strains, plasmids, and growth conditions. The strains and plasmids used in this study

242 are listed in Table 1. E. coli JM109 was used as the cloning host, and was grown in

243 lysogeny broth (LB) medium (containing $5.0 \mathrm{~g} / \mathrm{L}$ yeast extract, $10.0 \mathrm{~g} / \mathrm{L}$ tryptone, and

$24410.0 \mathrm{~g} / \mathrm{L} \mathrm{NaCl}$ ) at $37^{\circ} \mathrm{C}$ and $220 \mathrm{rpm}$. The engineered SSAAI (CGMCC No.15170) was

245 constructed in our laboratory by knocking out 591 bp of the C-terminal domain of serA,

246 deleting $s d a A$, avtA, and alaT, as well as attenuating $i l v B N$ in the genome of $C$.

247 glutamicum SYPS-062-33a (CGMCC No. 8667). The seed and fermentation media for $C$.

248 glutamicum were prepared as described previously (5). The C. glutamicum strains were

249 pre-incubated in the seed medium overnight to an optical density $\left(\mathrm{OD}_{562}\right)$ of about 25 ,

250 and then inoculated at an initial concentration of $\mathrm{OD}_{562}=1$ into a $250 \mathrm{~mL}$ flask containing 
$25125 \mathrm{~mL}$ of the fermentation medium at $30^{\circ} \mathrm{C}$ and $120 \mathrm{rpm}$. The antibiotic kanamycin $(50$

$252 \mathrm{mg} / \mathrm{L}$ ) was added when necessary. Samples were withdrawn periodically for the

253 measurement of residual sugar, amino acids, and $\mathrm{OD}_{562}$ as described previously (5).

254 Construction of plasmids and strains. The primers used in this study for gene

255 expression/deletion are listed in Table S2. Gene deletion was performed using the

256 nonreplicable deletion vector pK18mobsacB, as reported previously (33). For example, to

257 achieve thrE deletion, the homologous-arm fragments for thrE deletion were amplified

258 from SSAAI chromosome using the primer pairs $t h r E 1 / 2$ for the upstream fragment and

259 thrE3/4 for the downstream fragment. Then, with the two fragments as templates, a

260 crossover PCR was performed using the primer pair thrE1/4. The truncated product of

261 thrE was digested with $X b a \mathrm{I}$ and HindIII and ligated to the vector pK18mobsacB that was

262 similarly treated. The recombinant plasmid pK18mobsacB $\Delta$ thrE was transformed into

263 SSAAI competent cells by electroporation, and chromosomal deletion was performed by

264 selecting cells that were kanamycin resistant and sucrose nonresistant, and verified by

265 PCR.

266 The pDXW-10 and pDXW-11 plasmids were used to overexpress genes in $C$.

267 glutamicum $(34,35)$. The recombinant plasmids were constructed as follows: the genes

268 thrE and serE were amplified, digested, and ligated to the pDXW-10 plasmid that was 
269 digested with HindIII/BglII. The plasmid harboring the fusion protein, SerE-EGFP

270 (enhanced green fluorescent protein) was constructed by using the method reported in a

271 previous study (16). To confirm the role of NCg10581 on NCg10580 expression, the

272 fragment consisting of intergenic region of $\mathrm{NCg} 10581$ and $\mathrm{NCg} 10580$ and EGFP with or

273 without NCg10581 was ligated to the plasmid pDXW-11 by Clon Express MultiS One

274 Step Cloning Kit (Vazyme, Nanjing, China). The strains were constructed by

275 electroporation with the corresponding plasmids.

276 Confocal microscopic observation. The strains SSAAI-10 (SSAAI harboring plasmid

277 pDXW-10), SSAAI-egfp, and SSAAI-serE-egfp were grown in the seed medium and

278 harvested during the exponential phase. The cells were washed twice and maintained in

279 PBS (pH 7.4), mounted on a microscope slide, and observed under a Leica laser scanning

280 confocal microscope (Leica, TCS SP8; Leica, Wetzlar, Germany) equipped with a HC PL

281 Apo 63x/1.40 Oil CS2 oiL-Immersion objective, with excitation filter at $488 \mathrm{~nm}$ and

282 emission filter at 510-550 $\mathrm{nm}$. The digital images were acquired and analyzed with Lecia

283 Application Suite X 2.0.

284 Membrane and cytoplasmic protein extraction and fluorescence measurements.

285 The strains SSAAI-10, SSAAI-egfp, and SSAAI-serE-egfp were used for extracting

286 membrane and cytoplasmic proteins to determine SerE localization. The extraction was 
287 performed using Membrane and a Cytoplasmic Protein Extraction Kit according to the

288 manufacturer's protocol (Beyotime, Nanjing, China). The cells were washed twice with

289 PBS ( $\mathrm{pH}$ 7.4) and disrupted by ultrasonication on ice (pulse, 4 s; interval, $6 \mathrm{~s}$; total

290 duration, 30 min) (Sonics Vibra-Cell ${ }^{\mathrm{TM}}$, Sonics, Newtown, CT, USA). The supernatant

291 containing cytoplasmic proteins was collected by centrifugation $\left(700 \times g, 4{ }^{\circ} \mathrm{C}\right.$ for 10

$292 \mathrm{~min}$ ), and the precipitate was used for extracting membrane proteins. The protein

293 concentration was determined with a Modified BCA Protein Assay Kit (Sangon, China).

294 After extraction, the fluorescence intensity (excitation at $488 \mathrm{~nm}$, emission at $517 \mathrm{~nm}$ ) of

295 the membrane and cytoplasmic proteins was determined using fluorescence

296 spectrophotometer (Synergy H4; BioTek, Winooski, VT, USA).

297 Amino acid export assay. For ascertaining the function of serE, a dipeptide Ser-Ser

298 addition assay was conducted (12). In brief, pre-incubated cells (in seed medium) were

299 washed once with CGXII minimal medium (36), inoculated into CGXII minimal medium

300 with $2 \mathrm{mM} \mathrm{Ser-Ser}$ (other dipeptide), and incubated for $2 \mathrm{~h}$ at $30^{\circ} \mathrm{C}$. Then, the cells were

301 harvested, washed once with cold CGXII minimal medium, and resuspended in CGXII

302 minimal medium. Amino acid excretion was initiated by adding $2 \mathrm{mM}$ Ser-Ser (another

303 dipeptide). HPLC was used to determine the concentrations of amino acids (16).

304 Analytical procedures. Cell density $\left(\mathrm{OD}_{562}\right)$ was measured using an AOE UV-1200S 
305 UV/vis spectrophotometer (AOE Instruments Co. Inc., Shanghai, China). Glucose

306 concentration was determined using SBA-40E glucose analyzer (Biology Institute of

307 Shandong Academy of Sciences, China). For measurement of extracellular L-serine

308 concentration in shake-flask fermentation, $500 \mu \mathrm{L}$ of the culture were centrifuged at 700

$309 \times g$ for $5 \mathrm{~min}$, and the supernatant was used for detection after appropriate dilution. To

310 ascertain intracellular L-serine concentration, $300 \mu \mathrm{L}$ of the culture were centrifuged at

$311700 \times g$ and $4^{\circ} \mathrm{C}$ for $10 \mathrm{~min}$, and $300 \mu \mathrm{L}$ of water were added to the cells. The cells were

312 disrupted by FastPrep-24 5G instrument (5 m/s, 120 s, MP Biomedicals, Shanghai,

313 China). The cytoplasmic volume was assumed to be $2 \mu \mathrm{L} / \mathrm{mg}$ dry cell weight (23). The

314 titers of intracellular and extracellular L-serine and other amino acids were analyzed by

315 HPLC using phenylisothiocyanate as a precolumn derivatization agent, according to our

316 previously study (24).

317 EMSA. To identify the binding site of NCg10581 in the NCg10580 promoter region,

318 EMSA was conducted by using Non-Radioactive EMSA Kits with Biotin-Probes User's

319 Manual VER. 5.11 (Viagene Biotech Inc, Changzhou, China), according to the

320 manufacturer's instruction. The consensus oligonucleotides were BIO-JNZXM-TP (5'-

321 AAACAGCCAA CTATAGTTAAGTAATA-3') and BIO-JNZXM-BM (5'-

322 TATTACTTAACTATAGTTGGCTGTTT-3’). 


\section{ACKNOWLEDGMENTS}

324 This work was financially supported by the National Natural Science Foundation of

325 China (No. 31600044). Program of National First-class Discipline Program of Light

326 Industry Technology and Engineering (LITE2018-11). Program of Introducing Talents of

327 Discipline to Universities (No.111-2-06). International Joint Research Laboratory for

328 Engineering Synthetic Biosystem for Intelligent Biomanufacturing at Jiangnan University.

329 Top-notch Academic Programs Project of Jiangsu Higher Education Institutions (TAPP).

330 And China Postdoctoral Science Foundation (No.2018M640452).

\section{REFERENCES}

332 1. Mundhada H, Seoane JM, Schneider K, Koza A, Christensen HB, Klein T, Phaneuf PV,

333 Herrgard M, Feist AM, Nielsen AT. 2017. Increased production of L-serine in

334 Escherichia coli through Adaptive Laboratory Evolution. Metab Eng 39: 141-150.

335 2. Zhang X, Xu G, Shi J, Koffas MAG, Xu Z. 2018. Microbial production of L-serine

336 from renewable feedstocks. Trends Biotech 36 (7): 700-712.

337 3. Peters-Wendisch P, Stolz M, Etterich H, Kennerknecht N, Sahm H, Eggeling L. 2005.

338 Metabolic engineering of Corynebacterium glutamicum for L-serine production. Appl 339 Environ Microbiol 71:7139-7144.

340 4. Stolz M, Peters-Wendisch P, Etterich H, Gerharz T, Faurie R, Sahm H, Fersterra H,

341 Eggeling L. 2007. Reduced folate supply as a key to enhanced L-serine production by

342 Corynebacterium glutamicum. Appl Environ Microbiol 73:750-755. 
343 5. Zhu Q, Zhang X, Luo Y, Guo W, Xu G, Shi J, Xu Z. 2015. L-serine overproduction

344 with minimization of by-product synthesis by engineered Corynebacterium glutamicum.

345 Appl Microbiol Biotechnol 99:1665-1673.

346 6. Zhang XM, Lai LH, Xu GQ, Zhang XJ, Shi JS, Koffas MAG, Xu ZH. 2019. Rewiring

347 the central metabolic pathway for high-yield L-serine production in Corynebacterium

348 glutamicum by using glucose. Biotechnol J DOI: 10.1002/biot.201800497.

349 7. Eggeling L. 2016. Exporters for production of amino acids and other small molecules.

350 Adv Biochem Eng Biotechnol 159:199-225.

351 8. Pérez-García F, Wendisch VF. 2018. Transport and metabolic engineering of the cell

352 factory Corynebacterium glutamicum. FEMS Microbiol Lett 365:11.

353 9. Vrljic M, Sahm H, Eggeling L. 2010. A new type of transporter with a new type of

354 cellular function: L-lysine export from Corynebacterium glutamicum. Mol Microbiol

$355 \quad 22: 815-826$.

356 10. Dassler T, Maier T, Winterhalter C, Bock A. 2000. Identification of a major facilitator

357 protein from Escherichia coli involved in efflux of metabolites of the cysteine pathway.

358 Mol Microbiol 36:1101-1112.

359 11. Jun N, Seiko H, Hisao I, Masaaki W. 2007. Mutations of the Corynebacterium

360 glutamicum NCg11221 gene, encoding a mechanosensitive channel homolog, induce L-

361 glutamic acid production. Appl Environ Microbiol 73:4491-4498.

362 12. Simic P, Sahm H, Eggeling L. 2001. L-threonine export: use of peptides to identify a 363 new translocator from Corynebacterium glutamicum. J Bacteriol 183:5317-5324. 
364 13. Lubitz D, Jorge JMP, Pérez-García F, Taniguchi H, Wendisch VF. 2016. Roles of

365 export genes $\operatorname{cgm} \mathrm{A}$ and lys $\mathrm{E}$ for the production of L-arginine and L-citrulline by

366 Corynebacterium glutamicum. Appl Microbiol Biotechnol 100:1-10.

367 14. Schwede T. 2013. Protein modeling: What happened to the "protein structure gap"?

368 Structure 21:1531-1540.

369 15. Petra S, Juliane W, Hermann S, Lothar E. 2002. Identification of glyA (encoding 370 serine hydroxymethyltransferase) and its use together with the exporter ThrE to increase

371 L-threonine accumulation by Corynebacterium glutamicum. Appl Environ Microbiol $37268: 3321$.

373 16. Liu Q, Liang Y, Zhang Y, Shang X, Liu S, Wen J, Wen T. 2015. YjeH is a novel 374 exporter of L-methionine and branched-chain amino acids in Escherichia coli. Appl 375 Environ Microbiol 81:7753.

376 17. Huhn S, Jolkver E, Kramer R, Marin K. 2011. Identification of the membrane protein

377 SucE and its role in succinate transport in Corynebacterium glutamicum. Appl Microbiol

378 Biotechnol 89:327-335.

379 18. Maddocks SE, Oyston PCF. 2008. Structure and function of the LysR-type 380 transcriptional regulator (LTTR) family proteins. Microbiol 154:3609-3623.

381 19. Bellmann A, Vrlji M, Pátek M, Sahm H, KrMer R, Eggeling L. 2001. Expression

382 control and specificity of the basic amino acid exporter LysE of Corynebacterium 383 glutamicum. Microbiol 147:1765.

384 20. Xiuling S, Yun Z, Guoqiang Z, Xin C, Aihua D, Yong L, Tingyi W. 2013. 385 Characterization and molecular mechanism of AroP as an aromatic amino acid and 386 histidine transporter in Corynebacterium glutamicum. J Bacteriol 195:5334-5342. 
387 21. Nicole K, Hermann S, Ming-Ren Y, Miroslav P, Jr MH, Saier, Lothar E. 2002. Export

388 of L-isoleucine from Corynebacterium glutamicum: a two-gene-encoded member of a

389 new translocator family. J Bacteriol 184:3947-3956.

390 22. Wang Y, Cao G, Xu D, Fan L, Wu X, Ni X, Zhao S, Zheng P, Sun J, Ma Y. 2018. A

391 novel L-glutamate exporter of Corynebacterium glutamicum. Appl Environ Microbiol 84

392 (6): e02691-17.

393 23. Zhi Z, Jiu-Yuan D, Tang L, Ning-Yi Z, Shuang-Jiang L. 2011. The ncgl1108 (PheP

394 (Cg)) gene encodes a new L-phe transporter in Corynebacterium glutamicum. Appl

395 Microbiol Biotechnol 90:2005-2013.

396 24. Eggeling L, Sahm H. 2003. New ubiquitous translocators: amino acid export by

397 Corynebacterium glutamicum and Escherichia coli. Arch Microbiol 180:155-160.

398 25. Christian TT, Dietrich D, Brigitte B, Andreas B, Reinhard KM. 2005.

399 Characterization of methionine export in Corynebacterium glutamicum. J Bacteriol $400 \quad 187: 3786$.

401 26. Jie Y, Jingpeng G, Johanna H, Erwin S, Maojun Y. 2015. Structural basis for

402 substrate specificity of an amino acid ABC transporter. P NATL ACAD SCI USA $403 \quad 112: 5243-5248$.

404 27. Jones CM, Lozada NJ, Hernández, Pfleger BF. 2015. Efflux systems in bacteria and 405 their metabolic engineering applications. Appl Microbiol Biotechnol 99:9381-9393.

406 28. Nandineni MR, Gowrishankar J. 2004. Evidence for an arginine exporter encoded by $407 \operatorname{yggA}(\arg O)$ that is regulated by the LysR-type transcriptional regulator $\operatorname{Arg} P$ in 408 Escherichia coli. J Bacteriol 186:3539-3546. 
29. Marbaniang CN, Gowrishankar J. 2012. Transcriptional cross-regulation between

410 Gram-negative and gram-positive bacteria, demonstrated using $\operatorname{Arg} P$-argO of

411 Escherichia coli and LysG-lysE of Corynebacterium glutamicum. J Bacteriol 194:5657-

4125666.

413 30. Binder S. 2012. A high-throughput approach to identify genomic variants of bacterial

414 metabolite producers at the single-cell level. Genome Biol13(5):R40.

415 31. Zhang $X$, Zhang $X, X u$ G, Zhang $X$, Shi J, Xu Z. 2018. Integration of ARTP

416 mutagenesis with biosensor-mediated high-throughput screening to improve 1 -serine

417 yield in Corynebacterium glutamicum. Appl Microbiol Biotechnol 102:1-13.

418 32. Shah A, Blombach B, Gauttam R, Eikmanns BJ. 2018. The RamA regulon: complex

419 regulatory interactions in relation to central metabolism in Corynebacterium glutamicum.

420 Appl Microbiol Biotechnol 102:1-10.

421 33. Schafer A, Tauch A, Jager W, Kalinowski J, Thierbach G, Puhler A. 1994. Small

422 mobilizable multipurpose cloning vectors derived from the Escherichia-coli plasmids

423 pk18 and pk19-selection of defined deletions in the chromosome of Corynebacterium-

424 glutamicum. Gene 145:69-73.

425 34. Xu DQ, Tan YZ, Shi F, Wang XY. 2010. An improved shuttle vector constructed for

426 metabolic engineering research in Corynebacterium glutamicum. Plasmid 64:85-91.

427 35. Xu D, Tan Y, Li Y, Wang X. 2011. Construction of a novel promoter-probe vector

428 and its application for screening strong promoter for Brevibacterium flavum metabolic

429 engineering. World J Microbiol Biotechnol 27:961-968.

430 36. Keilhauer C, Eggeling L, Sahm H. 1993. Isoleucine synthesis in Corynebacterium

431 glutamicum: molecular analysis of the ilvB-ilvN-ilvC operon. J Bacteriol 175:5595. 
439 TABLE 1 Strains and plasmids used in this study.

\begin{tabular}{|c|c|c|}
\hline Strain/Plasmid & Description & Sources or reference \\
\hline \multicolumn{3}{|l|}{ E. coli } \\
\hline JM109 & recA1, endA1, gyrA96, thi-1, hsdR17, supE44, relA1 & Laboratory strain \\
\hline \multicolumn{3}{|l|}{ C. glutamicum } \\
\hline SSAAI & \multicolumn{2}{|l|}{$\begin{array}{l}\text { C. glutamicum SYPS-33a with deletion of the } 591 \text { bp in the C- } \\
\text { terminus of serA, deletion of sdaA,alaT,avta and attenuation of (5) } \\
\text { ilvBN }\end{array}$} \\
\hline SSAAI-thrE & SSAAI harboring plasmid pDXW-10-thrE & This study \\
\hline $\mathrm{SSAAI} \Delta t h r E$ & SSAAI with deletion of $t h r E$ & This study \\
\hline $\mathrm{SSAAI} \Delta \mathrm{NCgl} 2050$ & SSAAI with deletion of NCg12050 & This study \\
\hline $\mathrm{SSAAI} \Delta \mathrm{NCgl} 2065$ & SSAAI with deletion of NCg12065 & This study \\
\hline $\mathrm{SSAAI} \Delta \mathrm{NCg} 10580$ & SSAAI with deletion of $\mathrm{NCg} 10580$ & This study \\
\hline SSAAI-10 & SSAAI harboring plasmid pDXW-10 & This study \\
\hline SSAAI-egfp & SSAAI harboring plasmid pDXW-10-egfp & This study \\
\hline SSAAI-serE-egfp & SSAAI harboring plasmid pDXW-10-serE-egfp & This study \\
\hline $\mathrm{SSAAI} \Delta \mathrm{NCgl0581}$ & SSAAI with deletion of NCg10581 & This study \\
\hline SSAAI $\triangle \mathrm{NCg10581-1}$ & SSAAI $\Delta$ NCg10581 harboring pDXW-11-1 & This study \\
\hline SSAAI $\triangle \mathrm{NCg10581-0}$ & $\mathrm{SSAAI} \Delta \mathrm{NCgl0581}$ harboring pDXW-11-0 & This study \\
\hline SSAAI $\triangle N C g 10580-$ serE & $\mathrm{SSAAI} \Delta \operatorname{serE}$ harboring plasmid pDXW-10-serE (NCg10580) & This study \\
\hline
\end{tabular}




\begin{tabular}{|c|c|c|}
\hline Strain/Plasmid & Description & Sources or reference \\
\hline SSAAI-serE & SSAAI harboring plasmid pDXW-10-serE (NCg10580) & This study \\
\hline ATCC13032 & Wild type & Laboratory strain \\
\hline ATCC13032 $\Delta$ serE & ATCC13032 with deletion of $\operatorname{serE}(\mathrm{NCg10580)}$ & This study \\
\hline pK18mobsacB & Integration vector, oriV, oriT, $m o b, s a c B, \mathrm{Km}^{\mathrm{r}}$ & (33) \\
\hline pK18mobsacB $\Delta t h r E$ & $\begin{array}{l}\text { pK18mobsacB carrying the up- and downstream homologous } \\
\text { fragments of } t h r E \text { gene for } t h r E \text { deletion }\end{array}$ & This study \\
\hline pK18mobsacB $\Delta \mathrm{NCg} 12050$ & $\begin{array}{l}\text { pK18mobsacB carrying the up- and downstream homologous } \\
\text { fragments of NCg12050 gene for NCg12050 deletion }\end{array}$ & This study \\
\hline pK18mobsacB $\Delta \mathrm{NCgl} 2065$ & $\begin{array}{l}\text { pK18mobsacB carrying the up- and downstream homologous } \\
\text { fragments of NCg12065 gene for NCg12065 deletion }\end{array}$ & This study \\
\hline pK18mobsacB $\triangle \mathrm{NCg} 10580$ & $\begin{array}{l}\text { pK18mobsacB carrying the up- and downstream homologous } \\
\text { fragments of NCg10580 gene for NCg10580 deletion }\end{array}$ & This study \\
\hline pK18mobsacB $\Delta \mathrm{NCg} 10581$ & $\begin{array}{l}\text { pK18mobsacB carrying the up- and downstream homologous } \\
\text { fragments of NCg10581 gene for NCg10581 deletion }\end{array}$ & This study \\
\hline pDXW-10 & E. coli-C. glutamicum shuttle vector, tacM promoter, $\mathrm{Km}^{\mathrm{r}}$ & (34) \\
\hline pDXW-10-thrE & pDXW-10 carrying the gene of $t h r E$ & This study \\
\hline pDXW-10-serE & pDXW-10 carrying the gene of serE & This study \\
\hline pDXW-10-egfp & pDXW-10 carrying the gene of $e g f p$ & This study \\
\hline pDXW-10-egfp-serE & $\begin{array}{l}\text { pDXW-10 carrying the gene of egfp and serE for the } \\
\text { expression of fusion protein EGFP-SerE }\end{array}$ & This study \\
\hline pDXW-11 & E. coli-C. glutamicum shuttle vector, probe plasmid, $\mathrm{Km}^{\mathrm{r}}$ & $(35)$ \\
\hline pDXW-11-1 & $\begin{array}{l}\text { pDXW-11 carrying the fragments of } \mathrm{NCg} 10581 \text {, the intergenic } \\
\text { region between } \mathrm{NCgl} 0581 \text { and } \mathrm{NCgl} 0580 \text {, and } e g f p\end{array}$ & This study \\
\hline pDXW-11-0 & $\begin{array}{l}\text { pDXW-11 carrying the fragments of the intergenic region } \\
\text { between NCg10581 and NCg10580, and } e g f p\end{array}$ & This study \\
\hline
\end{tabular}

$440 \quad \mathrm{Km}^{\mathrm{r}}$, kanamycin resistance. 
451 TABLE 2 The genes significantly up regulated by NCgl0581 deletion

\begin{tabular}{lcccl}
\hline Gene id & $\begin{array}{c}\text { SSAAI } \\
\text { (0581 }\end{array}$ & SSAAI & $\begin{array}{c}\text { Fold } \\
\text { change }\end{array}$ & Protein function \\
\hline NCg12897 & 701.56 & 71.07 & 9.87 & Starvation-inducible DNA-binding protein \\
NCg10546 & 17.78 & 2.75 & 6.45 & Hypothetical protein \\
NCg11405 & 15.94 & 2.71 & 5.88 & ABC transporter periplasmic component \\
NCg11302 & 10.05 & 1.96 & 5.13 & Aldo/keto reductase \\
NCg11344 & 286.87 & 55.96 & 5.12 & Ornithine carbamoyltransferase \\
NCg11343 & 280.65 & 57.24 & 4.9 & Acetylornithine aminotransferase \\
NCg10746 & 43.30 & 9.04 & 4.7 & Hypothetical protein \\
NCg11342 & 134.70 & 29.07 & 4.63 & Acetylglutamate kinase \\
NCg12946 & 672.93 & 155.87 & 4.31 & Hypothetical protein \\
NCgl1022 & 89.53 & 21.28 & 4.20 & Cysteine sulfinate desulfinase \\
NCg11023 & 368.88 & 88.67 & 4.15 & Nicotinate-nucleotide pyrophosphorylase \\
NCg11341 & 108.49 & 27.09 & 4.00 & Bifunctional ornithine acetyltransferase/N-acetylglutamate \\
& & & & synthase \\
\hline
\end{tabular}


454 TABLE 3 The genes significantly down regulated by NCg10581 deletion

\begin{tabular}{lcccl}
\hline Gene id & SSAAI & SSAAI & $\begin{array}{c}\text { Fold } \\
\text { change }\end{array}$ & Protein function \\
\hline NCg10580 & 18.40 & 5152.54 & 280.02 & Hypothetical protein \\
NCg10638 & 1.71 & 20.97 & 12.22 & ABC transporter permease \\
NCg10639 & 11.00 & 82.47 & 7.49 & ABC transporter periplasmic component \\
NCg12943 & 207.03 & 1355.55 & 6.54 & Hypothetical protein \\
NCg10943 & 16.19 & 103.52 & 6.39 & AraC family transcriptional regulator \\
NCg10484 & 2.32 & 14.57 & 6.28 & ABC transporter permease \\
NCg12942 & 283.52 & 1776.15 & 6.26 & NADH: flavin oxidoreductase \\
NCg10166 & 13.41 & 79.70 & 5.94 & Hypothetical protein \\
NCg10324 & 2.11 & 11.87 & 5.61 & Zn-dependent alcohol dehydrogenase \\
NCg10282 & 5.19 & 28.25 & 5.44 & 4-Hydroxyphenyl-beta-ketoacyl-CoA hydrolase \\
NCg11975 & 102.94 & 503.75 & 4.89 & Hypothetical protein \\
NCg12893 & 1.25 & 6.08 & 4.84 & Efflux system protein \\
NCg10155 & 9.11 & 43.69 & 4.79 & 5-Dehydro-2-deoxygluconokinase \\
NCg10014 & 10.02 & 47.76 & 4.76 & Hypothetical protein \\
NCg12953 & 7.68 & 35.80 & 4.66 & Sugar permease \\
NCg12744 & 12.26 & 55.19 & 4.50 & Hypothetical protein \\
NCg12970 & 15.22 & 67.51 & 4.43 & ABC transporter periplasmic component \\
NCg10608 & 23.06 & 100.35 & 4.35 & ABC transporter permease \\
NCg10258 & 4.51 & 19.50 & 4.32 & Arsenite efflux pump ACR3 \\
NCg10281 & 16.83 & 67.69 & 4.02 & Dehydrogenase \\
\hline & & & \\
\hline
\end{tabular}


$462 \quad$ Figures legends

463 FIG 1 Effect of NCgl2050, NCgl2065, NCgl0580 deletion and plasmid compensating

464 strain on SSAAI.

465 (A) SSAAI $\triangle \mathrm{NCg1} 2050$ (Open symbols), SSAAI (Solid symbols).

466 (B) SSAAI $\triangle \mathrm{NCg1} 2065$ (Open symbols), SSAAI (Solid symbols).

467 (C) SSAAI $\triangle \mathrm{NCg10580} \mathrm{(Open} \mathrm{symbols),} \mathrm{SSAAI} \mathrm{(Solid} \mathrm{symbols).}$

468 (D) The plasmid compensating strain SSAAI $\triangle$ N0580-NCg10580 (Open symbols). SSAAI

469 (Solid symbols).

470 Squares and circles indicate growth $\mathrm{OD}_{562}$ and L-serine titer, respectively.

471 Three parallel experiments were performed. Error bars indicate standard deviations of

472 results from three parallel experiments.

473 FIG 2 The fluorescence of cytoplasmic proteins and membrane proteins.

474 The fluorescence of cytoplasmic proteins and membrane proteins of SSAAI-10 (SSAAI

475 harboring plasmid pDXW-10 only, grey bar with slash), SSAAI-egfp (SSAAI expressing

476 EGFP protein with pDXW-10, Grey bar) and SSAAI-serE-egfp (SSAAI expressing SerE-

477 EGFP fusion protein with pDXW-10, White bar).

478 Three parallel experiments were performed. Error bars indicate standard deviations of

479 results from three parallel experiments. 
480 FIG 3 The result of amino acid export of SerE by using peptide feeding approach in

481 SSAAI.

482 (A) Extracellular concentration of L-serine in SSAAI (Solid symbols) and serE deletion

483 strain SSAAI $\Delta \operatorname{serE}$ (Open symbols).

484 (B) Extracellular concentration of L-threonine in SSAAI (Squares) and serE deletion

485 strain SSAAI $\Delta s e r E$ (Circles).

486 Three parallel experiments were performed. Error bars indicate standard deviations of

487 results from three parallel experiments.

488 FIG 4 The effect of $t h r E$, serE deletion or overexpression on SSAAI.

489 (A) The cell growth (Grey bar with slash), L-serine titer (White bar). SSAAI (S1), thrE

490 deletion strain (S2), serE deletion strain (S3), thrE and serE deletion strain (S4), thrE

491 overexpression strain (S5) and serE overexpression strain (S6).

492 (B) Growth $\mathrm{OD}_{562}$ of stain with thrE and serE double deletion, SSAAI (Solid squares),

493 SSAAI $\Delta t h r E-\Delta \operatorname{serE}$ (Open triangles), SSAAI $\Delta t h r E$ (Open squares) and SSAAI $\Delta \operatorname{ser} E$

494 (Open circles).

495 (C) L-serine titer of stain with $\operatorname{thrE}$ and $\operatorname{ser} E$ double deletion, SSAAI (Solid circles),

496 SSAAI $\Delta t h r E-\Delta s e r E$ (Open triangles), SSAAI $\Delta t h r E$ (Open squares) and SSAAI $\Delta s e r E$

497 (Open circles). 
498 (D) Growth $\mathrm{OD}_{562}$ of strains with serE overexpression, SSAAI-10 (Squares), SSAAI-

$499 \operatorname{serE}$ (Circles), and SSAAI $\Delta \operatorname{serE}$-serE (Triangles).

500 (E) L-serine titer of strains with serE overexpression, SSAAI-10 (Squares), SSAAI-serE

501 (Circles), and SSAAI $\Delta$ serE-serE (Triangles).

502 Three parallel experiments were performed. Error bars indicate standard deviations of

503 results from three parallel experiments.

504 FIG 5 Effect of NCgl0581 deletion on SSAAI.

505 The cell growth (Squares) and L-serine titer (Circles) of SSAAI (Solid symbols) and

$506 \mathrm{SSAAI} \Delta \mathrm{NCg10581}$ (Open symbols), respectively.

507 Three parallel experiments were performed. Error bars indicate standard deviations of

508 results from three parallel experiments. 
(A)

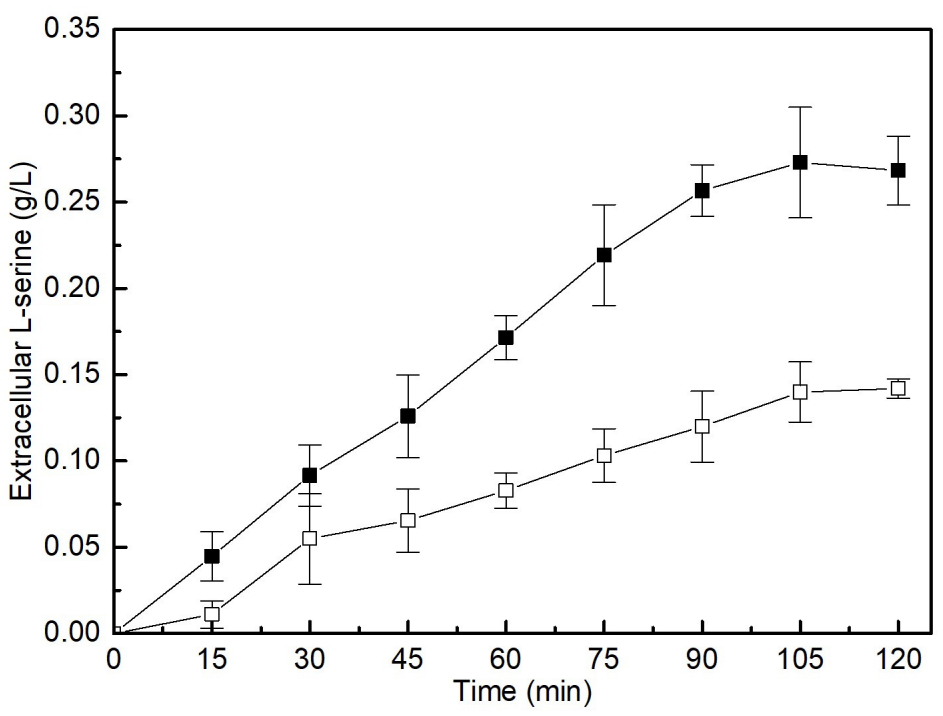

(B)

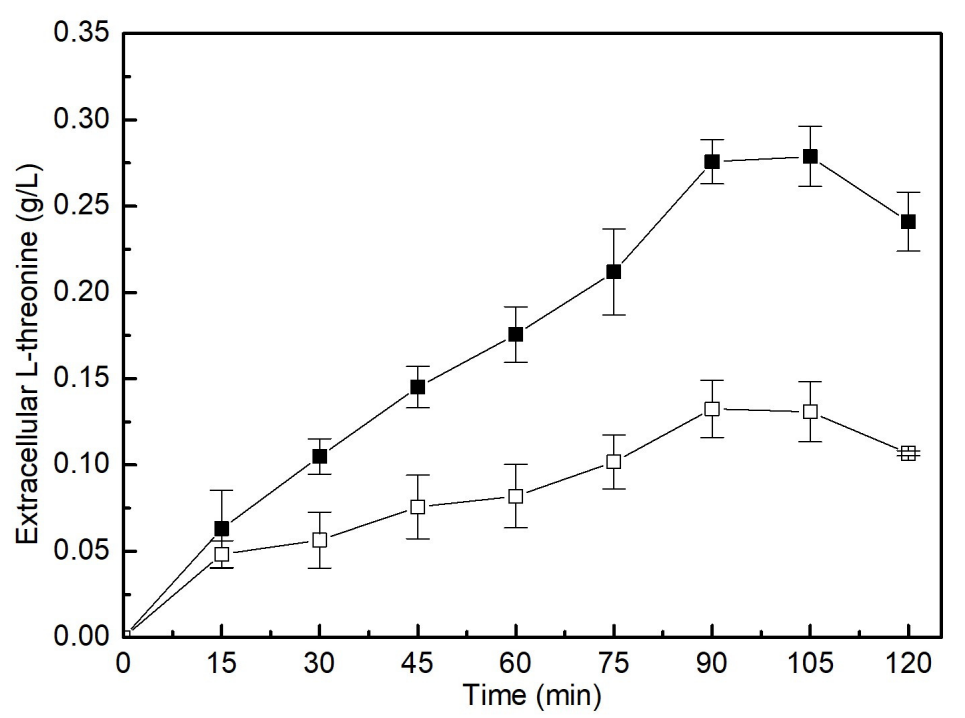


(A)

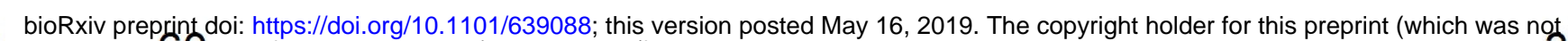

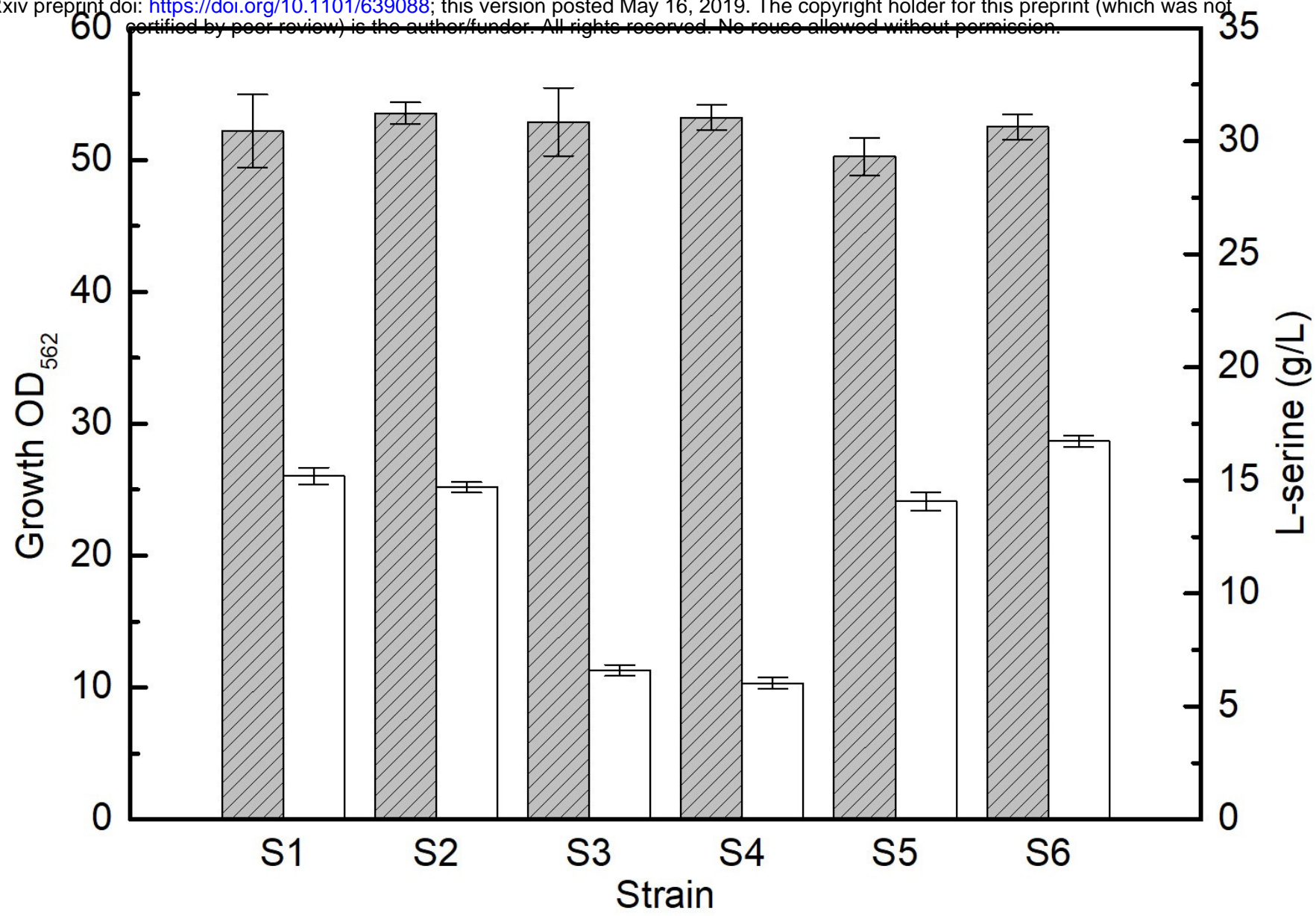

(B)

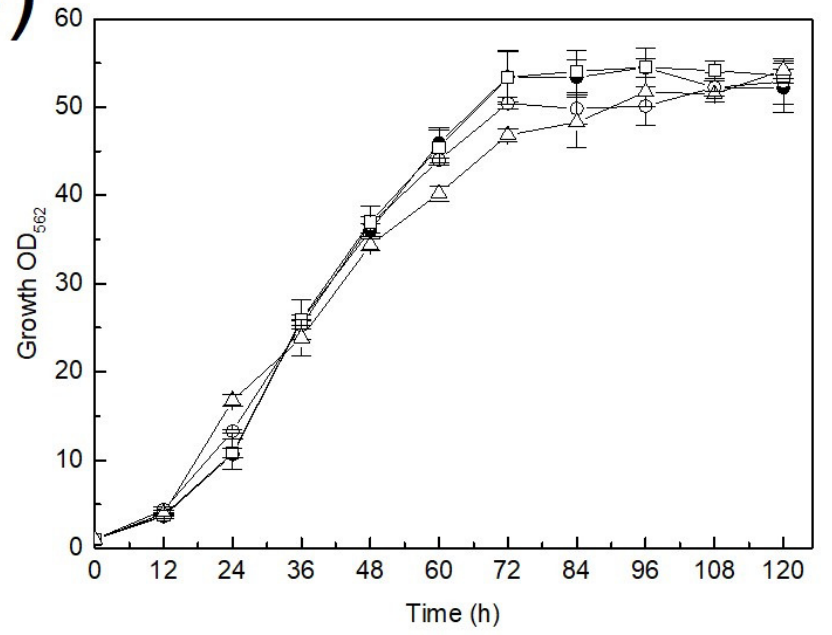

(D)

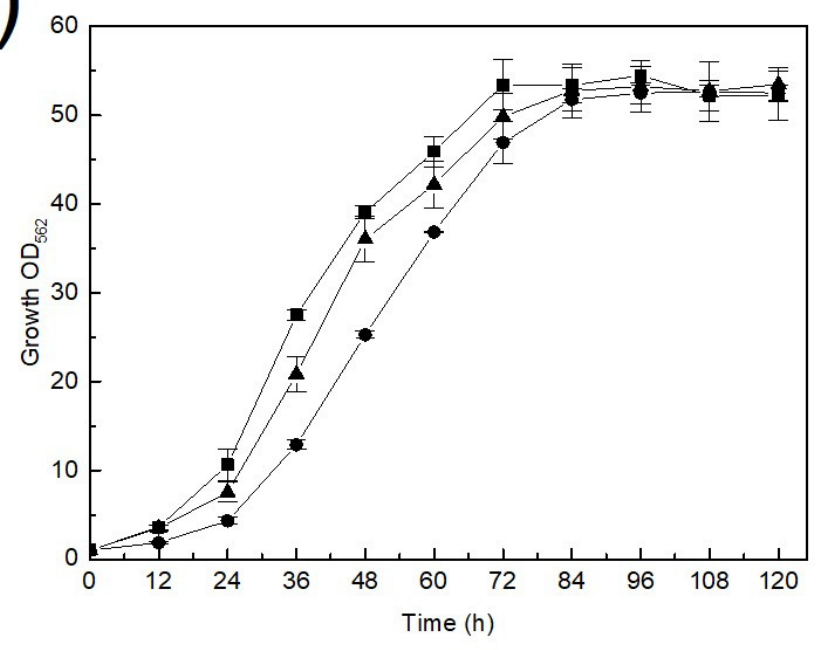

(C)

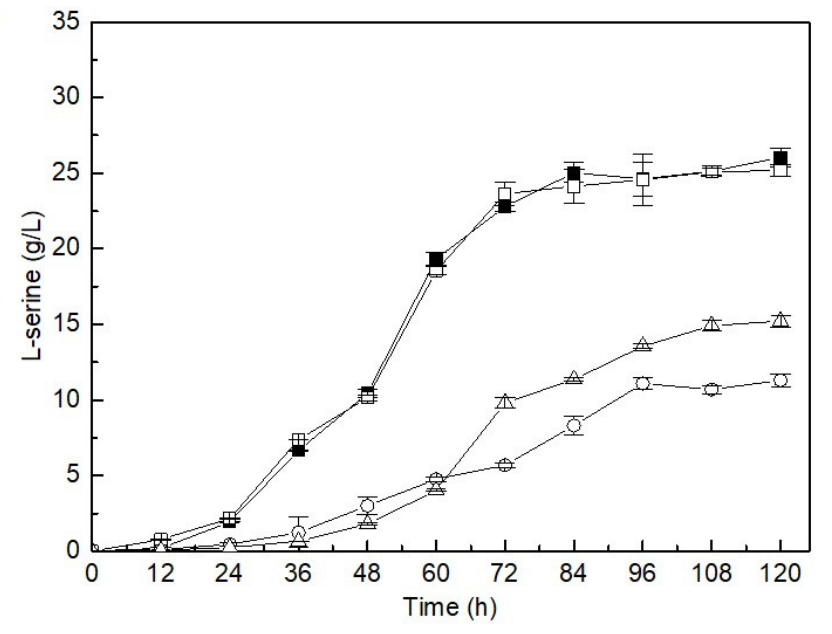

(E)

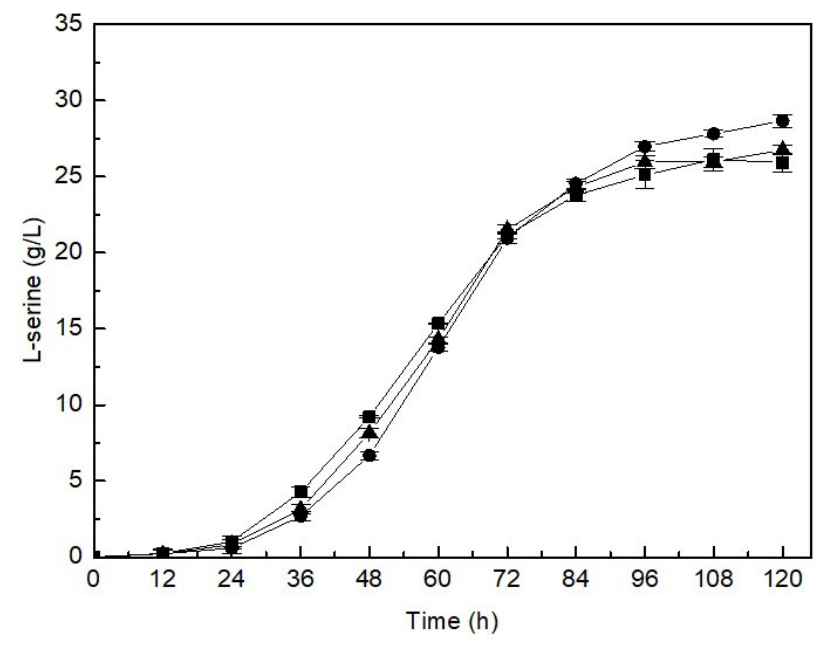


(A)

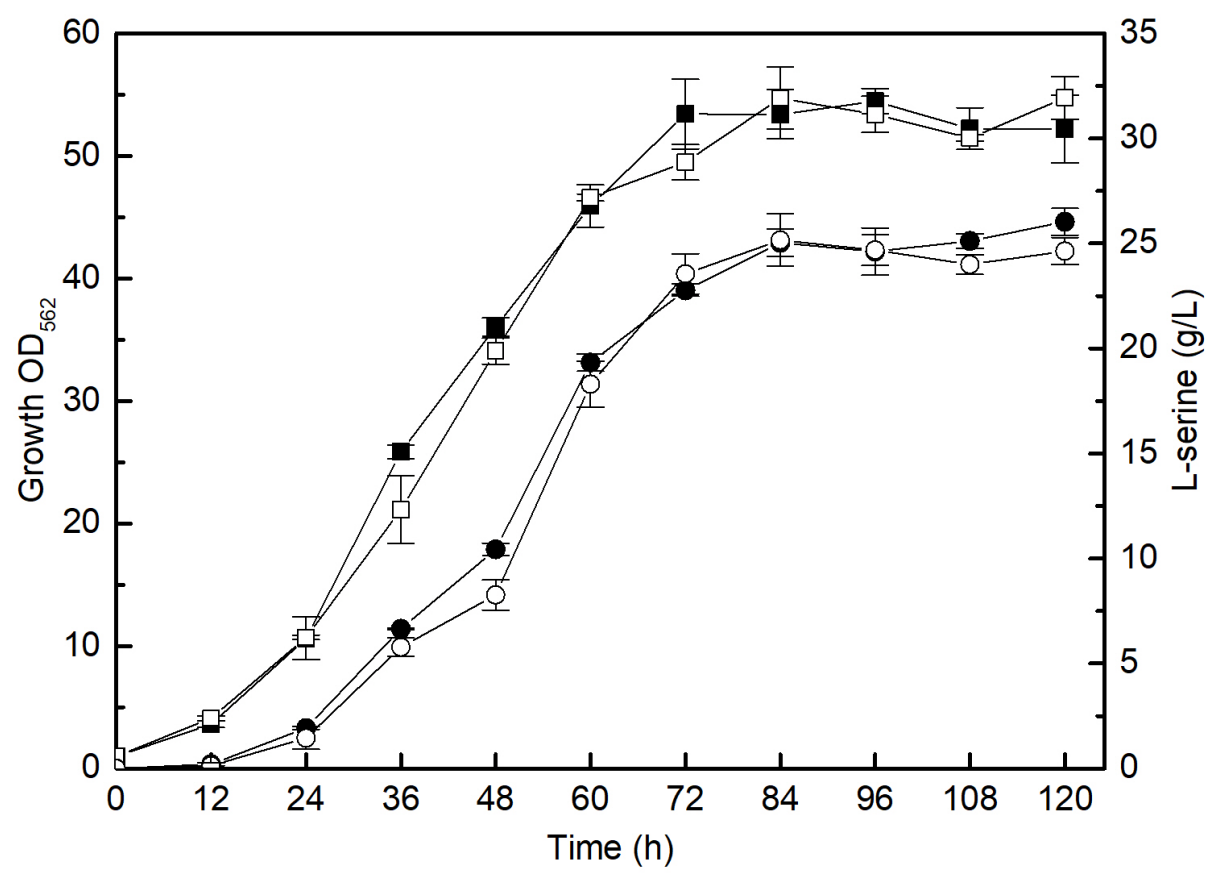

(C)

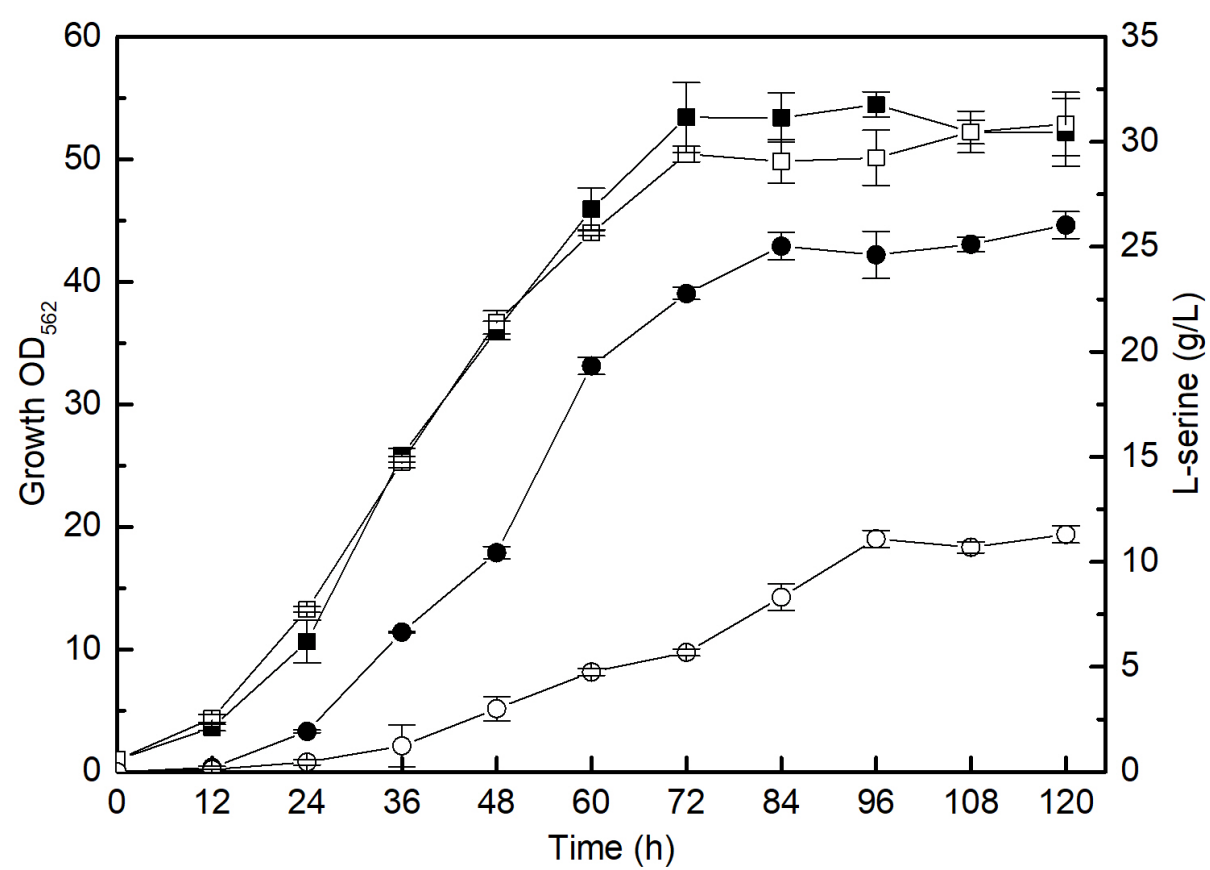

(B)

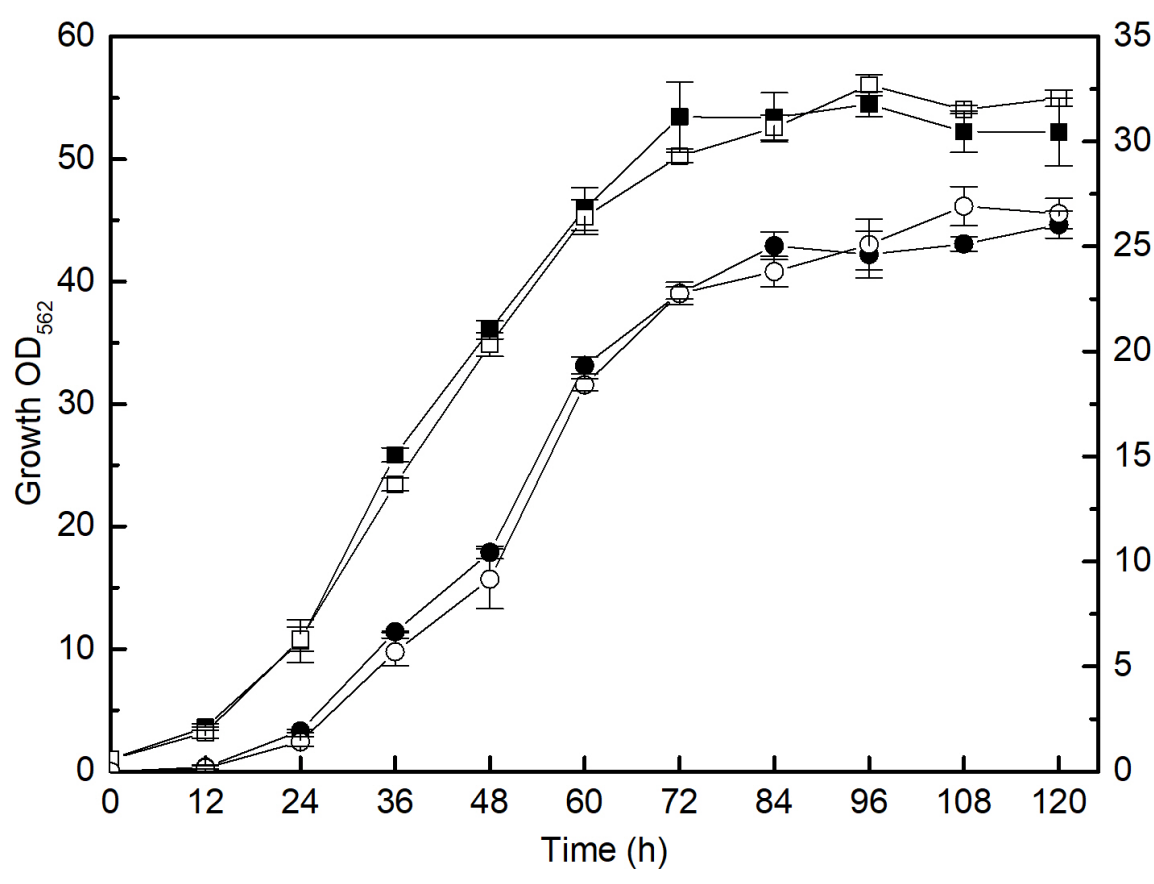

(D)

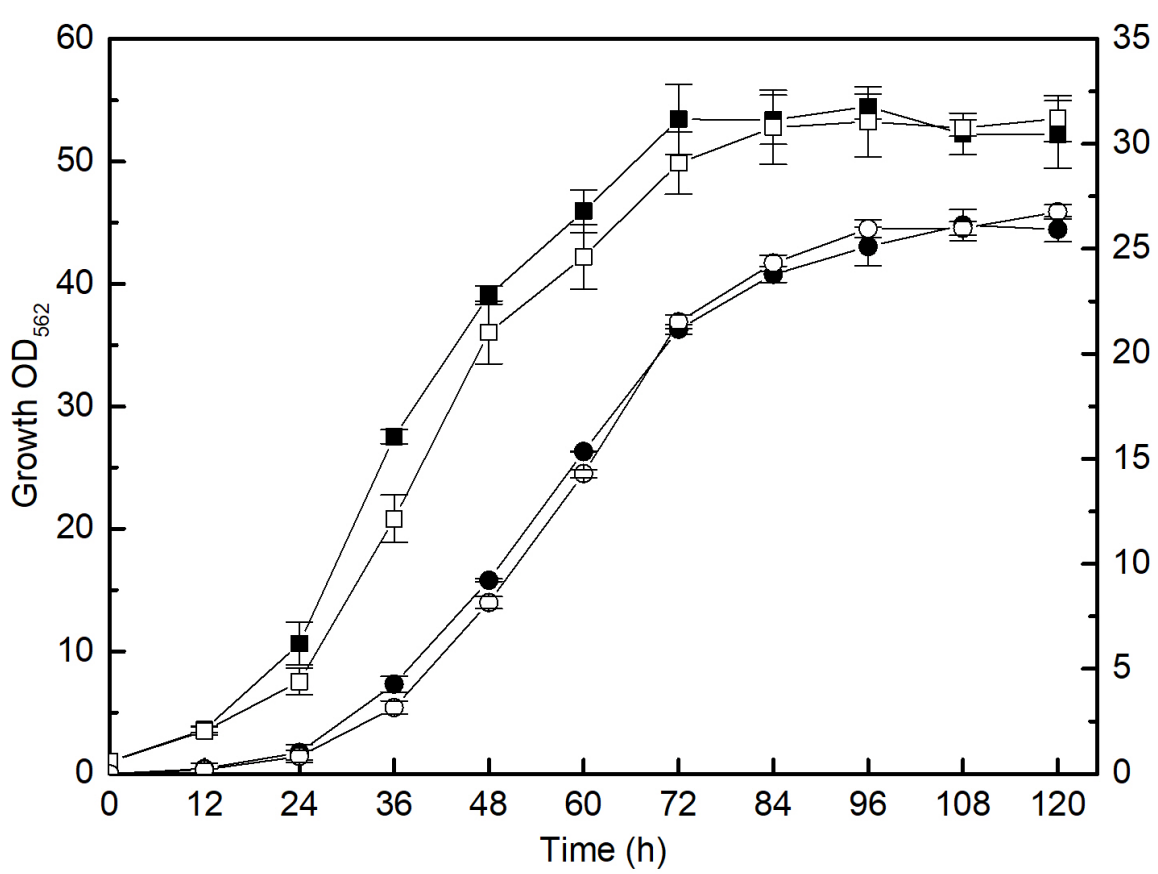




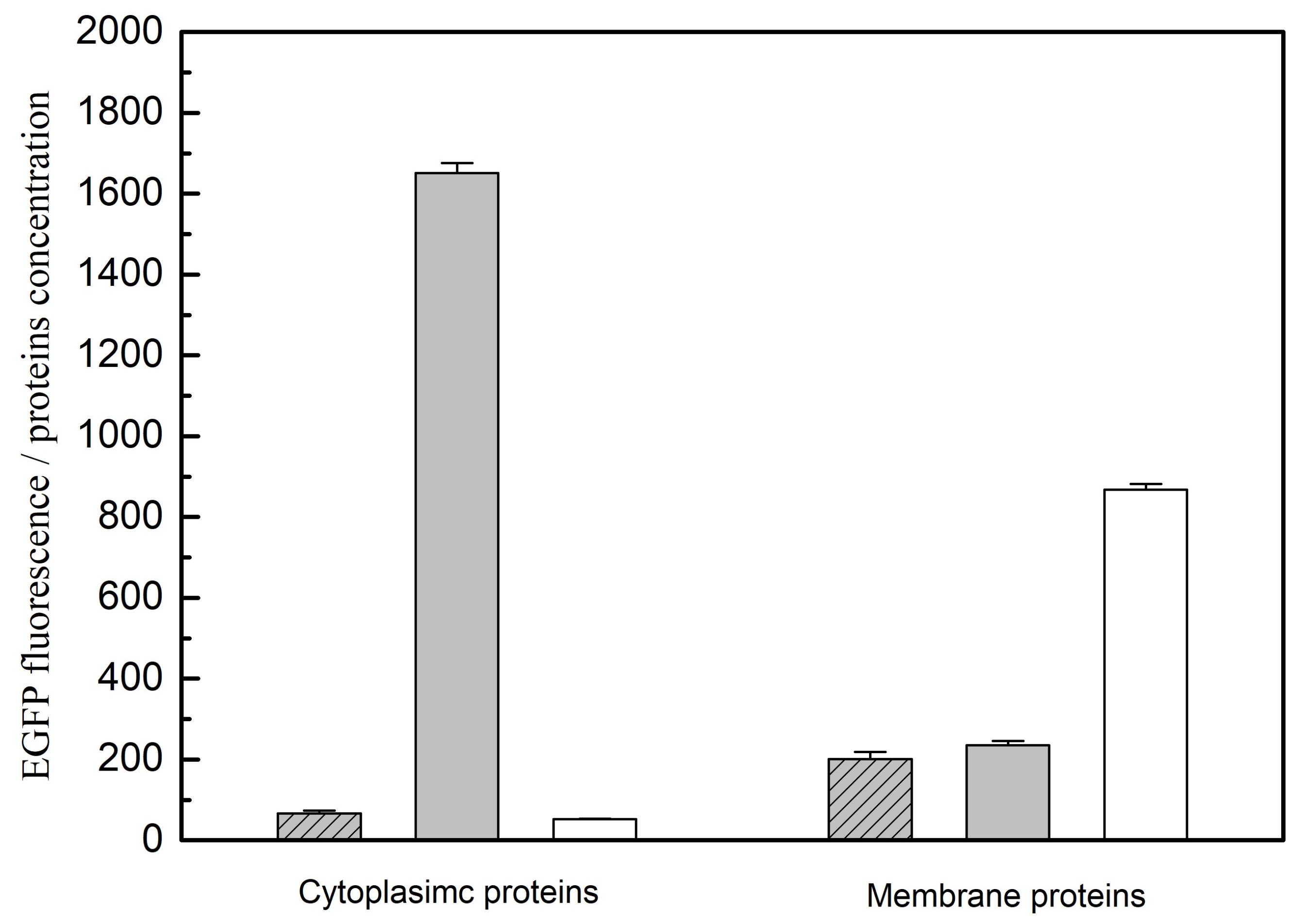


